\title{
INTERACTIVE EFFECTS BETWEEN BIOFERTILIZER AND ANTIOXIDANT ON SALINITY MITIGATION AND NUTRITION AND YIELD OF OKRA PLANTS (Abelmoschus esculentus L.)
} Mahdy, A.M. ${ }^{a, 1}$ and Nieven O. Fathi ${ }^{b}$

a- Dept. of Soil and Water, Fac. Agric., Alex. Univ., Elshatby, 21545, Alexandria, Egypt

b- Salinity and Alkalinity Soils Research Laboratory, Abis-Alexandria Ministry of Agriculture and Land Reclamation,(Egypt)

\begin{abstract}
A greenhouse pot experiment was conducted to explore how to alleviate the deleterious effects of saline-irrigation water on the growth and the yield of okra plants, as well as to limit the physiological and biochemical changes induced through salinity stress, bio-fertilization and antioxidant application. The soil was irrigated with saline water levels: tap water $(0.47), 2$, and $4 \mathrm{dSm}^{-1}$. The biofertilizer" Nitroben" treatments were applied as an inoculum to okra seeds before cultivation. The ascorbic acid levels (100 and $200 \mathrm{mg.}^{-1}$ ) were added as a foliar spray. The results revealed that salt stress caused significant reductions in growth variables including plant height and pods dry and fresh weights in comparison with the negative and positive controls. The combined treatments of biofertilizer and ascorbic acid significantly ameliorate the negative effects of salinity levels on okra growth parameters. The combined treatments of biofertilizer and ascorbic acid significantly increased total chlorophyll contents in leaves of okra plants. Also, the combined treatments of biofertilizer and ascorbic acid significantly increased ascorbic acid contents in okra plants compared with the contents of salinity affected plants. The increase of salinity levels significantly increased proline content in okra plants. The combined treatments of biofertilizer and ascorbic acid levels significantly ameliorate the negative effects of salinity levels on micro and macro-nutrients concentrations in okra plants. It can be concluded that T11 $\left(\right.$ Soil + S2 $\left(2.00 \mathrm{dSm}^{-1}\right)+$ ascorbic acid $\left(100 \mathrm{mg.l}^{-1}\right)+$ biofertilizer $)$ treatment was the best for the growth performance of okra plant.

Keywords: Ascorbic acid, biofertilizer, salinity, Okra, growth
\end{abstract}

\section{INTRODUCTION}

Irrigation with saline water, as a result of freshwater deficiency, might increase the risk of secondary salinization if irrigation management is unreasonable (Suarez, 1992). Salinity is one of the major environmental factors restricting plant growth and productivity especially in arid and semiarid regions. The deleterious effects of salinity on plant growth are associated with (i) osmotic stress, (ii) nutrient imbalance, (iii) specific ion toxicities, or (iv) a combination of these factors (Centritto et al., 2003). Salinity is known to inhibit photosynthesis in a number of plant species as a consequence of stomatal closure, thereby limiting $\mathrm{CO}_{2}$ diffusion into the chloroplasts (Hernández et al., 1999; Centritto et al., 2003; Degl'Innocenti et al., 2009).

\footnotetext{
${ }^{1}$ Corresponding author E.mail: amahdy73@ yahoo.com
} 
Biofertilizers are products containing living cells of different types of microorganisms, which have an ability to convert nutritionally important elements from unavailable to available form through biological processes (Hegde et al., 1999; Vessey, 2003) In recent years, biofertilizers have emerged as an important component of the integrated nutrient supply system and hold a great promise to improve crop yields through environmentally better nutrient supplies. Inoculation with Nitrobacter sp. under saline stress conditions is useful as it can accumulate compatible solutes, such as glycine betaine, glutamate, and proline, to allow adaptation to fluctuations in soil salinity.

Ascorbic acid (AsA) is one of the most important antioxidants abundantly occurring in plants (Smirnoff, 2000). Generally, its concentration is higher in leaves than that in other plant parts and it is 5-10 times higher than that of glutathione (GSH) (Smirnoff, 2005). The role of AsA as an antioxidant has been shown by Muller-Moule et al. (2003, 2004) who demonstrated that AsA deficient mutants of Arabidopsis (vtc mutants) were more sensitive to ozone, sulfur dioxide, or UV-B light (Veljovic-Jovanovic et al., 2001). Thus, high endogenous AsA in plants is necessary to counteract oxidative stress in addition to regulating other processes of plant metabolism. Endogenous AsA can be increased by exogenous application of AsA through the rooting medium (Chen and Gallie, 2004), as a foliar spray or as seed priming. Ascorbic acid is also involved in regulating photosynthetic capacity by controlling stomatal movement (Chen and Gallie, 2004). Ascorbate is also an important co-factor of some enzymes or protein complexes that are involved in the regulation of photosynthesis (Davey et al., 2000). However, detailed information on how AsA can cause changes in photosynthesis remains to be elucidated. Thus, to minimize the effects of oxidative salt stress, ascorbic acid is generally recommended. Ascorbic acid acts as a primary substrate in the cycling pathway of enzymatic detoxification of hydrogen peroxide (Foyer 1993; Smirnoff 1995). The objective of the present work was to explore how to alleviate the effects of saline-irrigation water on the growth and the yield of okra plants, as well as to limit the physiological and biochemical changes induced by salinity stress through bio-fertilization and antioxidant application.

\section{MATERIALS AND METHODS}

\section{Soil characteristics:}

The upper soil layer $(0-20 \mathrm{~cm})$ was collected from a farm at Almowazafeen Village, in the region of Abis, Alexandria, Egypt. The soil was air-dried and sieved through a 2-mm sieve. Sub-samples of the air-dried soil were used for the following chemical analysis: the $\mathrm{pH}$ and the electrical conductivity (EC) were determined in soil-paste extract (Richards, 1954), the organic matter content was determined by dichromate oxidation method (Nelson and Sommers, 1982), cation exchange capacity (CEC) was determined by IM NaOAC method (Rhoades, 1982), the particle size distribution was determined by the hydrometer method (Day, 1965), total 
calcium carbonate content was determined using calcimeter (Nelson, 1982), the available phosphorus was determined by $0.5 \mathrm{M} \mathrm{NaHCO}_{3}$ test (Olsen and Sommers, 1982), the available nitrogen was determined by $2 \mathrm{M} \mathrm{KCl}$ method (Bremner and Mulvaney, 1982), and the available potassium was determined by $1 \mathrm{~N}$ ammonium acetate method (Knudsen and Peterson,1982). The main chemical and physical properties of the soil are shown in Table (1).

Table (1): The main chemical and physical properties of the soil used.

\begin{tabular}{|l|c|c|}
\hline \multicolumn{1}{|c|}{ Parameter } & Unit & Abis soil \\
\hline $\mathrm{pH}\left(\mathrm{H}_{2} \mathrm{O}\right)$ & & $8.08 \pm 0.09$ \\
\hline $\mathrm{EC}$ & $\mathrm{dSm}$ & $2.11 \pm 0.34$ \\
\hline $\mathrm{CEC}$ & $\mathrm{Cmol}^{-1} \mathrm{~kg}^{-1}$ & $27.26 \pm 1.45$ \\
\hline Total $\mathrm{CaCO}_{3}$ & $\mathrm{~g} \cdot \mathrm{kg}^{-1}$ & $52.30 \pm 3.33$ \\
\hline $\mathrm{OC}$ & $\mathrm{g} \cdot \mathrm{kg}^{-1}$ & $11.95 \pm 0.99$ \\
\hline $\mathrm{OM}$ & $\mathrm{g} \cdot \mathrm{kg}^{-1}$ & $20.60 \pm 0.78$ \\
\hline Available-N & $\mathrm{g} \cdot \mathrm{kg}^{-1}$ & $142.24 \pm 0.89$ \\
\hline Available-P & $\mathrm{g} \cdot \mathrm{kg}^{-1}$ & $105.55 \pm 0.43$ \\
\hline Available-K $\mathrm{g}$ & $\mathrm{g} \mathrm{kg}^{-1}$ & $1328.85 \pm 6.43$ \\
\hline Clay & $\mathrm{g} \cdot \mathrm{kg}^{-1}$ & $341.20 \pm 9.22$ \\
\hline Silt & $\mathrm{g} \cdot \mathrm{kg}^{-1}$ & $104.90 \pm 4.23$ \\
\hline Sand & $\mathrm{g} \cdot \mathrm{kg}^{-1}$ & $553.90 \pm 5.87$ \\
\hline Texture & & $\mathrm{S} . \mathrm{C} . \mathrm{L}$ \\
\hline
\end{tabular}

"Means of three samples \pm SD.

† O.M: organic matter; S.C.L: sandy clay loam,

\section{Experimental set-up:}

A pot experiment was conducted using okra (Abelmoschus esculentus L.) as a test plant in polyethylene pots, each containing $10 \mathrm{~kg}$ sandy clay loam soil. The soil in each pot was irrigated with water of different salinity. The EC of each saline water was obtained by blending tap water with sea water, shaking and then measuring EC. The salinity(S) levels were: (tap water 0.47$), 2$, and $4 \mathrm{dSm}^{-1}\left(\mathrm{~S}_{1}, \mathrm{~S}_{2}\right.$, and $\left.\mathrm{S}_{3}\right)$, representing 100,75 , and $50 \%$ from the okra yield, respectively according to the data outlined by FAO,(1976) in all possible combinations. The Biofertilizer" Nitroben" treatments were applied as an inoculum to okra seeds before cultivation. It was purchased from Agricultural Research Centre, Ministry of Agriculture and Land Reclamation (MALR), Cairo, Egypt. Pots then left in the greenhouse, receiving only natural light, for 16 weeks, and watered weekly with tap water (EC $0.47 \mathrm{dS} \mathrm{\textrm {m } ^ { - 1 }}$ ) and/or saline water levels. Fertilization with the recommended rates of $\mathrm{N}, \mathrm{P}$, and $\mathrm{K}$ was accomplished according to MALR. The maximum and minimum temperatures in the greenhouse were 28 and $15^{\circ} \mathrm{C}$, respectively. Five seeds of okra were sown per pot then thinned to one plant after 7 days of germination. The ascorbic acid rates (100 and $200 \mathrm{mg.l}$ ${ }^{1}$ ) were added as a foliar spray twice after two and four weeks of sowing date. The experimental design was a split plot design with four replicates of each treatment. Okra was started yielding about 60 days after planting. The flowers were large, pale yellow and fairly ornamental. Each flower blooms for only 
one day and eventually formed one okra pod. Picking the pods when they were approximately $3-5 \mathrm{~cm}$ in length. Typically, it grows quickly, so we needed to harvest every two days or so and stopped harvesting as soon as the temperature started dropping down. The following growth and yield parameters were measured: plant height, pods fresh and dry weights. The salinity levels, biofertilizer, and / or ascorbic acid applications yielded a total of fourteen treatments $\left(T_{1}-T_{14}\right)$ :

$\mathrm{T}_{1}$ : Negative control (without any addititives)

$\mathrm{T}_{2}$ : Positive control ( $\left.100 \% \mathrm{NPK}\right)$

$\mathrm{T}_{3}$ : Soil $+\mathrm{S}_{2}\left(2.00 \mathrm{dSm}^{-1}\right)$

$\mathrm{T}_{4}$ : Soil $+\mathrm{S}_{3}\left(4.00 \mathrm{dSm}^{-1}\right)$

$\mathrm{T}_{5}$ : Soil $+\mathrm{S}_{2}\left(2.00 \mathrm{dSm}^{-1}\right)+$ biofertilizer

$\mathrm{T}_{6}$ : Soil $+\mathrm{S}_{3}\left(4.00 \mathrm{dSm}^{-1}\right)+$ biofertilizer

$\mathrm{T}_{7}$ : Soil $+\mathrm{S}_{2}\left(2.00 \mathrm{dSm}^{-1}\right)+$ Ascorbic acid (100 $\left.\mathrm{mg}^{-1} \mathrm{I}^{-1}\right)$

$\mathrm{T}_{8}$ : Soil $+\mathrm{S}_{2}\left(2.00 \mathrm{dSm}^{-1}\right)+$ Ascorbic acid $\left(200 \mathrm{mg}^{-l^{-1}}\right)$

$\mathrm{T}_{\mathrm{g}}$ : Soil $+\mathrm{S}_{3}\left(4.00 \mathrm{dSm}^{-1}\right)+$ Ascorbic acid $\left(100 \mathrm{mg}^{-l^{-1}}\right)$

$\mathrm{T}_{10}$ : Soil $+\mathrm{S}_{3}\left(4.00 \mathrm{dSm}^{-1}\right)+$ Ascorbic acid $\left(200 \mathrm{mg.l}^{-1}\right)$

$\mathrm{T}_{11}$ : Soil $+\mathrm{S}_{2}\left(2.00 \mathrm{dSm}^{-1}\right)+$ Ascorbic acid $\left(100 \mathrm{mg} \mathrm{.}^{-1}\right)+$ biofertilizer

$\mathrm{T}_{12}$ : Soil $+\mathrm{S}_{2}\left(2.00 \mathrm{dSm}^{-1}\right)+$ Ascorbic acid $\left(200 \mathrm{mg}^{-1} \mathrm{I}^{-1}\right)+$ biofertilizer

$\mathrm{T}_{13}$ : Soil $+\mathrm{S}_{3}\left(4.00 \mathrm{dSm}^{-1}\right)+$ Ascorbic acid $\left(100 \mathrm{mg}^{-\mathrm{I}^{-1}}\right)+$ biofertilizer

$\mathrm{T}_{14}$ : Soil $+\mathrm{S}_{3}\left(4.00 \mathrm{dSm}^{-1}\right)+$ Ascorbic acid $\left(200 \mathrm{mg}^{-\mathrm{I}^{-1}}\right)+$ biofertilizer

Soil sampling and analysis:

At harvest, the soil in each pot was mixed and a sample of soil was taken for the determination of EC, soluble cations, and soluble anions according to Richards (1954).

\section{Plant sampling and analysis:}

Samples of plants were collected after six weeks from sowing to study the growth characteristics and for chemical analysis of leaves except for total chlorophyll which were analysed in the upper fifth leaves of okra plants. After sampling of okra pods and leaves, immediately triple rinsed in distilled water to remove the adhering soil particles, then oven dried at $65^{\circ} \mathrm{C}$ for $48 \mathrm{~h}$ and the oven-dried matter yield was recorded. The oven-dried plant materials were ground in a stainless steel mill and subsamples were dry-ashed in a muffle furnace at $450^{\circ} \mathrm{C}$ for $6 \mathrm{~h}$. The ash was dissolved in $5 \mathrm{ml}$ of $\mathrm{HNO}_{3}$ (1: 1), diluted to a constant volume with distilled water and analysed for $\mathrm{K}, \mathrm{P}, \mathrm{Fe}$, $\mathrm{Mn}, \mathrm{Zn}, \mathrm{Cu}, \mathrm{Na}$, and $\mathrm{Cl}$ (Jones, 2001). Another sub-sample of plant material was ashed and dissolved in hydrochloric acid solution $(1: 1, \mathrm{v} / \mathrm{v})$, diluted to a certain volume with double-distilled water, and analysed for $\mathrm{N}$ (Jones, 2001) by Kjeldahl method (Bremner and Mulvaney, 1982). The dry matter production and plant nutrients concentrations are expressed on oven-dry weight basis.

\section{Chemical constituents:}

Six weeks after planting, the fifth leaf of plant was collected from each pot for chemical analyses. Chlorophylls was extracted from leaves by $80 \%$ acetone, and then determined ( $\mathrm{mg} \mathrm{g}^{-1} \mathrm{FW}$ ) by using a colorimetric method (Arnon 1949). Free proline was extracted by sulfosalicylic acid (3\%) then determined colorimetrically ( $\mathrm{mg} \mathrm{g}^{-1} \mathrm{DW}$ ) using acid minhydrin reagent as 
outlined by Bates et al.,(1973). Ascorbic acid was determined ( $\mathrm{mg} \mathrm{g}^{-1} \mathrm{FW}$ ) according to AOAC (1995).

Statistical and mathematical analyses:

The treatment effects on growth and yield parameters, chemical constituents, and nutrients concentrations were evaluated by analysis of variance (ANOVA) and also by the least significant difference (LSD) mean separation procedure at the 0.05 level of significance (SAS Institute, 1994).

The polynomial quadratic model was used to describe the relationship between ascorbic acid levels and pods dry matter yield of okra plants at different treatments of biofertilizer and salinity levels. The polynomial quadratic model used in the form:

$$
Y_{i}=B_{0}+B_{1} X_{i} \pm B_{2} X^{2}
$$

Where $Y_{i}$ the expected pods dry weight of okra plants, g.pot ${ }^{-1}$ corresponding to ascorbic acid level, mg. $\mathrm{g}^{-1}$ in each treatment $X i, B_{0}$ is the intercept and $B_{1}$, $B_{2}$ are the linear and quadratic coefficients, respectively.

\section{RESULTS}

\section{Electrical conductivity and soluble salts in soil after harvest of okra plants:}

At harvest, the EC of the soil was significantly $(P<0.05)$ changed due to salinity treatments with respect to the control soil (Table 2).The higher value of EC $\left(6.56 \mathrm{dSm}^{-1}\right)$ was recorded at $\mathrm{T}_{14}$ (Soil $+\mathrm{S}_{3}\left(4.00 \mathrm{dSm}^{-1}\right)+$ Ascorbic acid $\left(200 \mathrm{mg.l}^{-1}\right)+$ biofertilizer $)$ and the minimum $\left(1.88 \mathrm{dSm}^{-1}\right)$ was recorded with the negative control treatment $\left(T_{1}\right)$. In general, the salinity of soil extract, after harvest of okra plants, was significantly increased with increasing the salinity levels: $T_{3}$ and $T_{4}$ (Table 2). Application of biofertilizer and/ or ascorbic acid with these two treatments ( $T_{3}$ and $\left.T_{4}\right)$ was not significantly different as compared with salinity treatments (Table 2). The soluble ions, $\mathrm{Ca}, \mathrm{Mg}, \mathrm{Na}, \mathrm{K}, \mathrm{HCO}_{3}$ and $\mathrm{Cl}$, were significantly affected by salinity treatments (Table 2). The higher salinity level with respect to the control may reflect the amounts of soluble salts supplied to the soil through the irrigation with saline water (Table 2). Continuous flooding or frequent inundation can change these results. However, the maximum value of bicarbonate in soil was 6.00 meq. $I^{-1}$ and the maximum value of chloride was 24.88 meq. $I^{-1}$ and there were no adverse effects observed on okra growth during growth period. The combination between biofertilizer and ascorbic acid had positive effects on plant growth but had no any significant effects on soil properties after harvest of okra plants (Table 2). 
Table (2): Concentrations of water soluble ions in the soil extracts after okra harvest at different treatments.

\begin{tabular}{|l|c|c|c|c|c|c|c|}
\hline $\begin{array}{l}\text { Treatment } \\
\text { No. }\end{array}$ & \multirow{2}{*}{ EC, dSm $^{-1}$} & \multicolumn{6}{|c|}{ Water soluble ions, meq. $^{-1}$} \\
\cline { 3 - 7 } & & $\mathbf{C a}^{++}$ & $\mathbf{M g}^{++}$ & $\mathbf{N a}^{+}$ & $\mathbf{K}^{+}$ & $\mathbf{H C O 3}^{-}$ & $\mathbf{C l}^{-}$ \\
\hline T1 & $1.88 \pm 0.12$ & $3.12 \pm 0.22$ & $3.12 \pm 0.30$ & $6.11 \pm 0.66$ & $0.54 \pm 0.12$ & $2.66 \pm 0.55$ & $5.54 \pm 0.78$ \\
\hline T2 & $3.09 \pm 0.33$ & $4.32 \pm 0.35$ & $3.66 \pm 0.44$ & $13.09 \pm 1.52$ & $0.76 \pm 0.22$ & $2.83 \pm 0.42$ & $12.43 \pm 2.22$ \\
\hline T3 & $4.25 \pm 0.54$ & $5.53 \pm 0.56$ & $4.55 \pm 0.54$ & $17.55 \pm 2.33$ & $1.33 \pm 0.33$ & $4.76 \pm 0.77$ & $15.32 \pm 3.23$ \\
\hline T4 & $5.56 \pm 0.55$ & $6.66 \pm 0.55$ & $5.09 \pm 0.38$ & $22.23 \pm 3.33$ & $1.88 \pm 0.28$ & $6.00 \pm 0.74$ & $24.09 \pm 4.12$ \\
\hline T5 & $4.02 \pm 0.41$ & $3.88 \pm 0.43$ & $3.66 \pm 0.34$ & $14.43 \pm 2.11$ & $0.85 \pm 0.41$ & $1.95 \pm 0.21$ & $16.22 \pm 3.25$ \\
\hline T6 & $5.38 \pm 0.65$ & $5.65 \pm 0.57$ & $4.65 \pm 0.54$ & $21.21 \pm 3.12$ & $1.34 \pm 0.35$ & $4.22 \pm 0.36$ & $18.43 \pm 2.88$ \\
\hline T7 & $4.33 \pm 0.41$ & $4.08 \pm 0.54$ & $4.11 \pm 0.66$ & $15.54 \pm 3.01$ & $1.05 \pm 0.25$ & $2.12 \pm 0.32$ & $13.65 \pm 2.65$ \\
\hline T8 & $4.56 \pm 0.39$ & $4.22 \pm 0.87$ & $3.98 \pm 0.43$ & $14.12 \pm 2.56$ & $0.98 \pm 0.35$ & $2.43 \pm 0.41$ & $15.22 \pm 1.88$ \\
\hline T9 & $6.02 \pm 0.88$ & $6.12 \pm 1.02$ & $5.11 \pm 0.88$ & $24.53 \pm 4.55$ & $1.66 \pm 0.41$ & $5.54 \pm 0.45$ & $22.32 \pm 3.54$ \\
\hline T10 & $6.13 \pm 0.85$ & $6.08 \pm 1.01$ & $4.99 \pm 0.77$ & $24.32 \pm 4.36$ & $1.73 \pm 0.15$ & $5.00 \pm 0.65$ & $21.87 \pm 3.56$ \\
\hline T11 & $4.77 \pm 0.52$ & $4.12 \pm 0.88$ & $3.66 \pm 0.89$ & $13.54 \pm 2.66$ & $1.08 \pm 0.33$ & $3.08 \pm 0.78$ & $11.98 \pm 2.88$ \\
\hline T12 & $4.85 \pm 0.65$ & $3.98 \pm 0.54$ & $3.98 \pm 0.25$ & $14.00 \pm 2.88$ & $1.11 \pm 0.25$ & $3.22 \pm 0.56$ & $12.76 \pm 2.74$ \\
\hline T13 & $6.25 \pm 0.87$ & $6.09 \pm 0.89$ & $5.15 \pm 0.45$ & $25.65 \pm 4.29$ & $1.98 \pm 0.28$ & $4.97 \pm 0.66$ & $23.21 \pm 3.65$ \\
\hline T14 & $6.56 \pm 0.94$ & $6.44 \pm 0.88$ & $5.08 \pm 1.02$ & $27.04 \pm 4.52$ & $2.09 \pm 0.44$ & $5.65 \pm 0.68$ & $24.88 \pm 4.21$ \\
\hline LSD 0.05 & $\mathbf{0 . 2 1}$ & $\mathbf{0 . 2 8}$ & $\mathbf{0 . 3 8}$ & $\mathbf{1 . 2 2}$ & $\mathbf{0 . 2 2}$ & $\mathbf{0 . 3 2}$ & $\mathbf{1 . 1 5}$ \\
\hline
\end{tabular}

II Means of four samples \pm SD

Growth and yield parameters and polynomial quadratic model application:

Table (3) showed that salt stress $\left(T_{3}\right.$ and $\left.T_{4}\right)$ caused significant decrease in growth variables including plant height and pods dry and fresh weights in comparison with negative and positive controls $\left(T_{1} a n d T_{2}\right)$. As for the effect of various tested treatments on okra growth parameters, Table (3) indicated that addition of biofertilizer $\left(T_{5}\right.$ and $\left.T_{6}\right)$ significantly exceeded the growth and yield of that of the negative control. Also, ascorbic acid application rates $\left(T_{7}-T_{10}\right)$ significantly increased growth parameters of okra plants in comparison of negative control and approximately close to positive control values. Moreover, the combined treatments of biofertilizer and ascorbic acid levels significantly ameliorate the negative effects of salinity levels on okra growth parameters $\left(T_{11}-T_{14}\right)$. However, $T_{11}$ ( Soil + S2 $(2.00$ $\left.\mathrm{dSm}^{-1}\right)+$ ascorbic acid $\left(100 \mathrm{mg}^{-1} \mathrm{I}^{-1}\right)+$ biofertilizer) was the best followed by $\mathrm{T}_{12}>\mathrm{T}_{13}>\mathrm{T}_{14}$ (Table 3).

The polynomial quadratic model was used to describe the relationship between ascorbic acid and pods dry matter yield of okra plants at different treatments of biofertilizer and salinity levels. Using the method of the least squares, the experimental results of each pot was used to calculate the values of $B_{0}, B_{1}$ and $B_{2}$ in the polynomial model. Thus 4 polynomial quadratic models were established to express the relationship between ascorbic acid levels and pods dry matter yield of okra plants at different treatments of biofertilizer and salinity levels (Table 4). It is clear, therefore, that the calculated pods dry matter values were close to the experimental values as shown from the values of standard error of estimates (SE) and determination coefficient $\left(R^{2}\right)$. 
Table (3): Effects of salinity levels and biofertilization treatments on growth and yield parameters of okra plants at harvest.

\begin{tabular}{|l|c|c|c|}
\hline Treatment No. & Plant height, cm & Pods fresh weight, g/plant & Pods dry weight, g/plant \\
\hline T1 & $65.50 \pm 3.33$ & $33.15 \pm 3.22$ & $2.99 \pm 0.65$ \\
\hline T2 & $115.00 \pm 5.12$ & $88.23 \pm 2.76$ & $12.98 \pm 2.22$ \\
\hline T3 & $89.50 \pm 4.56$ & $66.12 \pm 3.44$ & $6.18 \pm 1.09$ \\
\hline T4 & $71.00 \pm 4.88$ & $42.23 \pm 5.23$ & $3.33 \pm 1.00$ \\
\hline T5 & $95.50 \pm 6.32$ & $73.11 \pm 3.55$ & $7.88 \pm 1.33$ \\
\hline T6 & $88.50 \pm 4.76$ & $46.98 \pm 3.54$ & $4.45 \pm 0.77$ \\
\hline T7 & $103.00 \pm 8.97$ & $77.76 \pm 3.88$ & $8.66 \pm 1.22$ \\
\hline T8 & $105.00 \pm 7.77$ & $75.88 \pm 4.23$ & $9.00 \pm 1.44$ \\
\hline T9 & $96.00 \pm 4.72$ & $55.12 \pm 2.34$ & $6.43 \pm 1.22$ \\
\hline T10 & $96.50 \pm 5.22$ & $56.32 \pm 1.99$ & $6.76 \pm 0.88$ \\
\hline T11 & $112.00 \pm 6.09$ & $89.21 \pm 4.55$ & $12.65 \pm 2.43$ \\
\hline T12 & $108.00 \pm 8.55$ & $90.12 \pm 5.12$ & $13.78 \pm 2.09$ \\
\hline T13 & $99.50 \pm 3.12$ & $68.32 \pm 2.54$ & $7.88 \pm 1.07$ \\
\hline T14 & $97.00 \pm 5.34$ & $71.00 \pm 2.45$ & $8.13 \pm 0.98$ \\
\hline LSD 0.05 & $\mathbf{4 . 5 3}$ & $\mathbf{5 . 1 1}$ & $\mathbf{1 . 7 6}$ \\
\hline
\end{tabular}

ףी Means of four samples \pm SD.

Table (4): Polynomial quadratic models expressing the relationships between ascorbic acid levels and pods dry weight of okra plants at different treatments of biofertilizer and salinity levels.

\begin{tabular}{|c|c|c|c|}
\hline Treatment & Equations & $\mathbf{R}^{2}$ & SE \\
\hline Salinity,2dSm ${ }^{-1}$ & $Y=-0.0001 X^{2}+0.0355 X+6.18$ & $0.99^{\star * *}$ & 0.14 \\
\hline Salinity,4dSm ${ }^{-1}$ & $Y=-0.0001 X^{2}+0.0499 X+3.33$ & $0.97^{\star \star \star}$ & 0.17 \\
\hline Salinity,2dSm ${ }^{-1}+$ biofertilizer & $Y=-0.0002 X^{2}+0.0659 X+7.88$ & $0.98^{* * *}$ & 0.15 \\
\hline Salinity,4dSm ${ }^{-1}+$ biofertilizer & $Y=-0.0002 X^{2}+0.0502 X+4.45$ & $0.99^{\star \star \star}$ & 0.12 \\
\hline
\end{tabular}

Total Chlorophyll and Chemical Constituents Contents:

Table (5) showed that salinity treatments $\left(T_{3}\right.$ and $\left.T_{4}\right)$ significantly decreased total chlorophyll contents in the leaves of okra plants by percentage of 22 and $47 \%$ at $\mathrm{T}_{3}$ and $\mathrm{T}_{4}$ respectively compared with total chlorophyll content at positive control $\left(T_{2}\right)$.Biofertilizer treatments $\left(T_{5}\right.$ and $\left.T_{6}\right)$ significantly decreased the reduction in total chlorophyll content occurred at salinity levels from 22 and $47 \%$ to 13 and $34 \%$ respectively (Table 5). Thus, application of biofertilizer improved and stimulated chlorophyll synthesis under salt stress. Ascorbic acid application rates $\left(T_{7}\right.$ and $\left.T_{8}\right)$ almost decreased the negative impact of low salinity level, $2 \mathrm{dSm}^{-1}$, on total chlorophyll content and slightly reduced the negative impact at high salinity level, $4 \mathrm{dSm}^{-1}$ (T9\&T10). On the contrary, the combined treatments of biofertilizer and ascorbic acid $\left(\mathrm{T}_{11}\right.$ and $\left.\mathrm{T}_{12}\right)$ significantly increased total chlorophyll contents in the leaves of okra plants, while, the combination of biofertilizer and ascorbic acid levels $\left(T_{13}\right.$ and $\left.T_{14}\right)$ had no significant effect on total chlorophyll contents in okra plants (Table 5). 
Table (5): Effects of salinity levels and biofertilization treatments on total chlorophyll, ascorbic acid and proline in okra plants.

\begin{tabular}{|c|c|c|c|}
\hline Treatment No. & Total chlorophyll, $\mathbf{~ m g . g ^ { - 1 }} \mathbf{F W}$ & Ascorbic acid, $\mathbf{~ m g . g}^{-1}$ & $\begin{array}{c}\text { Proline, } \\
\mathbf{m g}^{-1} \mathbf{g}^{-1}\end{array}$ \\
\hline T1 & $0.44 \pm 0.07$ & $0.18 \pm 0.05$ & $0.16 \pm 0.04$ \\
\hline T2 & $0.68 \pm 0.05$ & $0.36 \pm 0.07$ & $0.21 \pm 0.06$ \\
\hline T3 & $0.53 \pm 0.08$ & $0.18 \pm 0.04$ & $0.25 \pm 0.07$ \\
\hline T4 & $0.36 \pm 0.07$ & $0.11 \pm 0.04$ & $0.35 \pm 0.08$ \\
\hline T5 & $0.59 \pm 0.09$ & $0.22 \pm 0.05$ & $0.28 \pm 0.07$ \\
\hline T6 & $0.45 \pm 0.06$ & $0.17 \pm 0.06$ & $0.37 \pm 0.09$ \\
\hline T7 & $0.65 \pm 0.07$ & $0.22 \pm 0.04$ & $0.31 \pm 0.08$ \\
\hline T8 & $0.68 \pm 0.08$ & $0.28 \pm 0.08$ & $0.28 \pm 0.07$ \\
\hline T9 & $0.57 \pm 0.05$ & $0.25 \pm 0.09$ & $0.42 \pm 0.08$ \\
\hline T10 & $0.61 \pm 0.08$ & $0.33 \pm 0.09$ & $0.44 \pm 0.09$ \\
\hline T11 & $0.72 \pm 0.09$ & $0.38 \pm 0.09$ & $0.38 \pm 0.08$ \\
\hline T12 & $0.74 \pm 0.11$ & $0.37 \pm 0.08$ & $0.42 \pm 0.08$ \\
\hline T13 & $0.66 \pm 0.09$ & $0.27 \pm 0.07$ & $0.44 \pm 0.09$ \\
\hline T14 & $0.68 \pm 0.10$ & $0.32 \pm 0.08$ & $0.46 \pm 0.09$ \\
\hline LSD 0.05 & $\mathbf{0 . 1 3}$ & $\mathbf{0 . 0 6}$ & $\mathbf{0 . 0 4}$ \\
\hline
\end{tabular}

ף Means of four samples \pm SD.

Similarly, ascorbic acid contents were affected by Salinity levels $\left(\mathrm{T}_{3}\right.$ and $\mathrm{T}_{4}$ ) and significantly reduced in okra plants compared with total ascorbic acid content at positive control $\left(T_{2}\right)$. Biofertilizer treatments $\left(T_{5}\right.$ and $\left.T_{6}\right)$ significantly increased ascorbic acid contents compared with salt-affected plants but still lower than the positive control (Table 5). However, ascorbic acid contents at $\mathrm{T}_{7}-\mathrm{T}_{10}$ significantly increased in comparison of the values of ascorbic acid contents in salt-affected plants. Also, the combined treatments of biofertilizer and ascorbic acid levels $\left(T_{11}\right.$ and $\left.T_{14}\right)$ significantly increased ascorbic acid contents in okra leaves compared with the contents at salinity affected plants. However, the combination of biofertilizer and ascorbic acid levels had no significant effect on ascorbic acid contents in okra plants in comparison of positive control (Table 5).

Table 5 showed that increasing of salinity significantly increased proline content in okra plants. Also, biofertilizer treatments $\left(T_{5}\right.$ and $\left.T_{6}\right)$ significantly increased proline content in okra leaves compared with that of the positive control. Otherwise, there was no significant impact on proline contents in okra

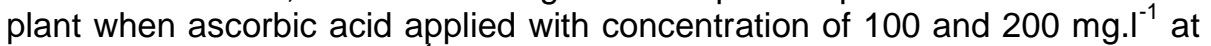
salinity treatment, $2 \mathrm{dSm}^{-1}$ (Table 4).While, there was significant effect on proline contents at $4 \mathrm{dSm}^{-1}$ treatment, on the contrary, the combined treatments of biofertilizer and ascorbic acid $\left(T_{11}\right.$ and $\left.T_{14}\right)$ significantly increased proline contents in okra leaves (Table 5).

It is clear from the obtained results that there were signifiant relationships between ascorbic acid or chlorophyll contents and pods dry and fresh weights(Fig.1A\&B), and no signifiant relationship between proline contents and pods dry or fresh weights(Fig.1C). 

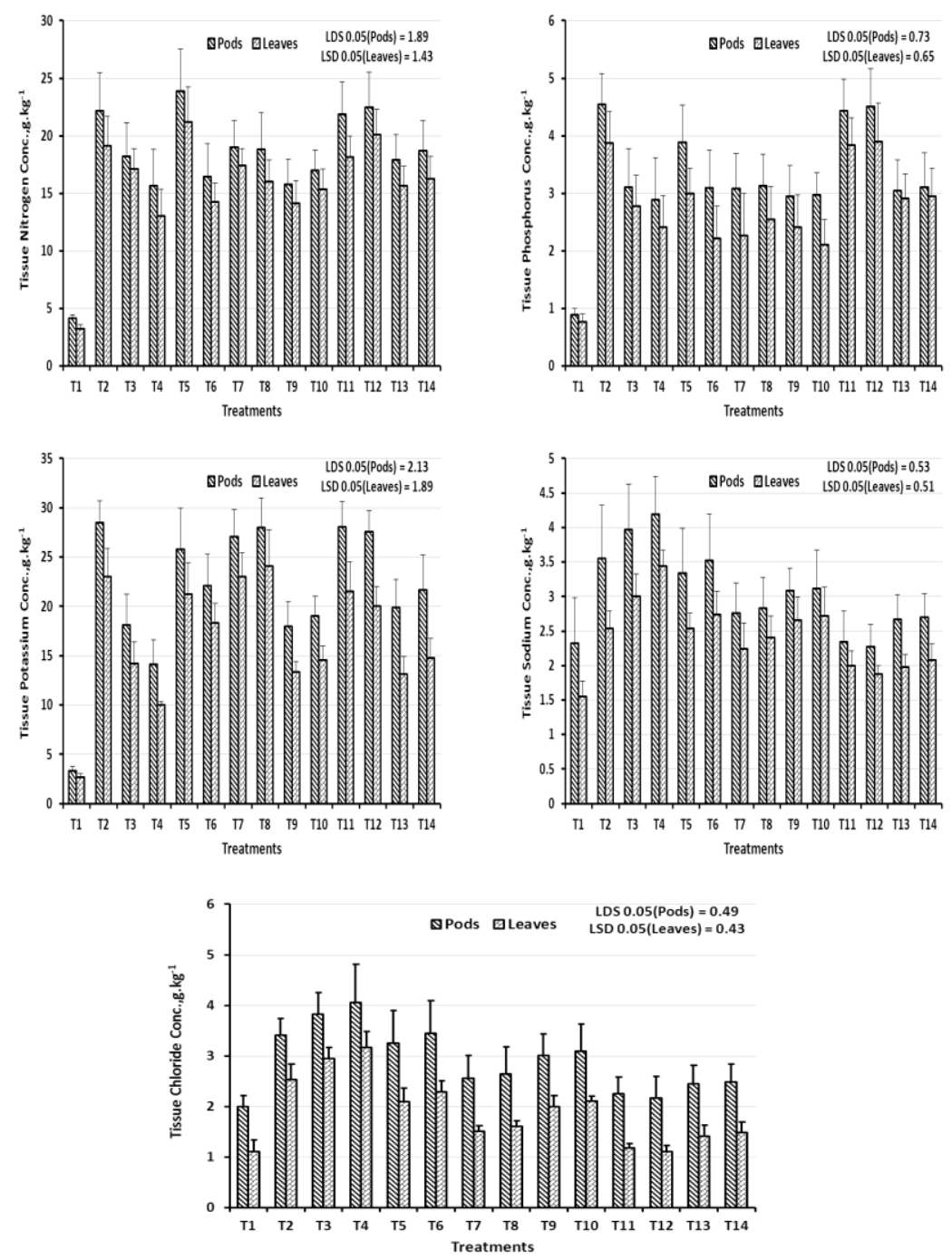

Fig.(1):Effects of soil salinity levels, biofertilization, and antioxidant treatments on $\mathrm{N}, \mathrm{P}, \mathrm{K}, \mathrm{Na}$, and $\mathrm{Cl}$ concentrations in tissues of okra plants( Error bars on all figures represent the standard error of the mean).

\section{Nutrients Contents in okra plant pods:}

Figure (2) demonstrates the effects of the tested factors on the elements contents in leaves and pods of okra plants. For two salinity levels $\left(T_{3}\right.$ and $\left.T_{4}\right)$, it was recorded that $N, P$ and $K$ decreased with increasing 
salinity while, $\mathrm{Na}$ and $\mathrm{Cl}$ concentrations were significantly increased with increasing salinity. Biofertilizer treatment $\left(T_{5}\right.$ and $\left.T_{6}\right)$ had significant effects on $\mathrm{N}, \mathrm{P}$ and $\mathrm{K}$ concentrations in okra plant as compared with salinity treated plants (Fig.2). The concentrations of $\mathrm{Na}$ and $\mathrm{Cl}$ in okra plants were higher than those of salinity treated plants when biofertilizer added to the seeds of okra plants. Similarly, application of ascorbic acids treatments had the same effects of biofertilizer on $N, P$, and $K$ concentrations in okra plants where significantly increased their concentrations in comparison of salinity treated plants, but there was no significant difference between biofertilizer and ascorbic acid treatments (Fig.2).
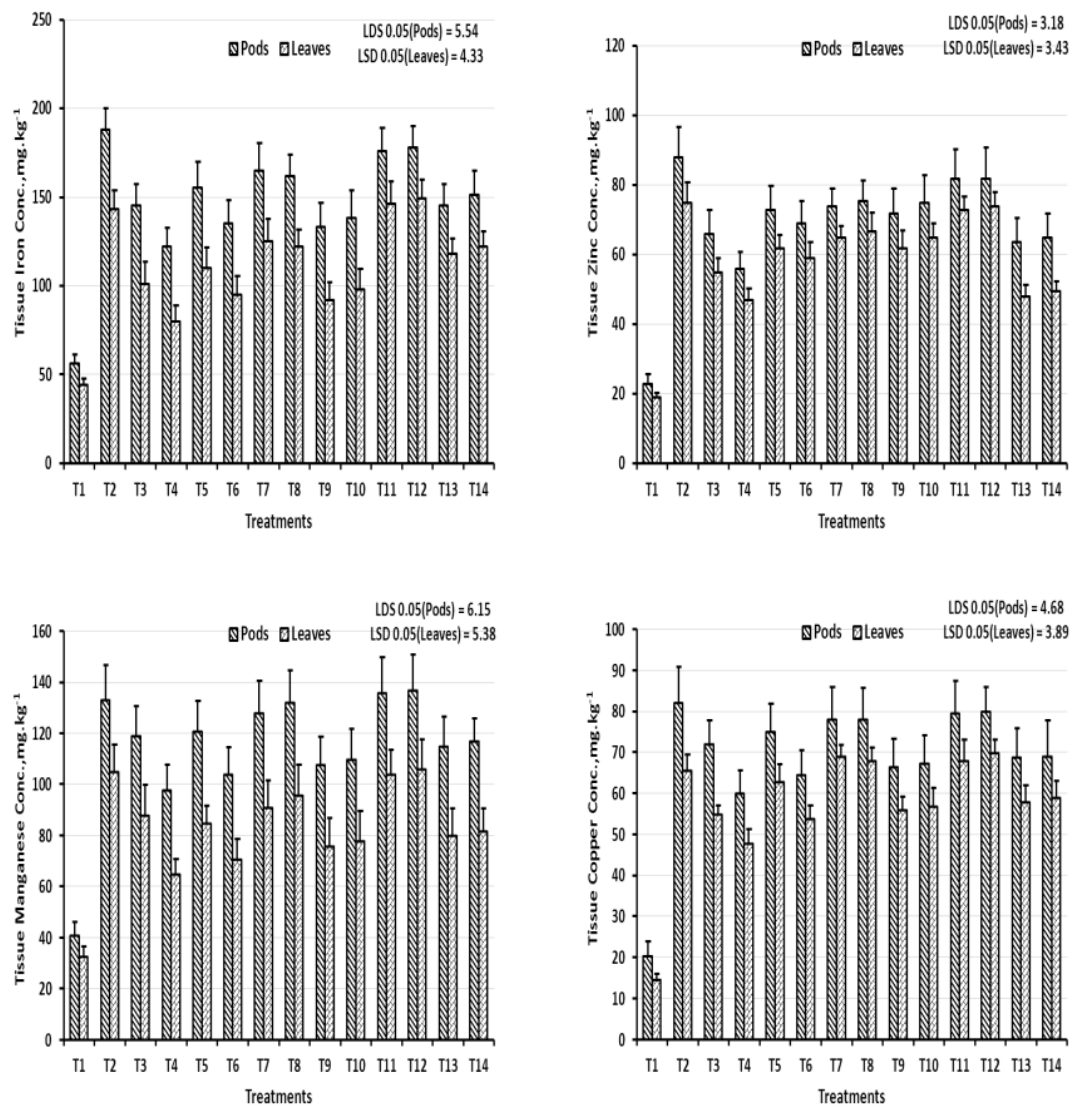

Fig.(2):Effects of soil salinity levels, biofertilization, and antioxidant treatments on $\mathrm{Fe}, \mathrm{Zn}, \mathrm{Mn}$, and $\mathrm{Cu}$ concentrations in tissues of okra plants ( Error bars on all figures represent the standard error of the mean).

On the other hand, application of ascorbic acid significantly decreased $\mathrm{Na}$ and $\mathrm{Cl}$ concentrations in okra plants in comparison of biofertilizer treatment. The combined treatments of biofertilizer and ascorbic acid ( $\mathrm{T}_{11}$ and $\left.\mathrm{T}_{14}\right)$ 
significantly increased concentrations of $\mathrm{N}, \mathrm{P}$, and $\mathrm{K}$ in okra plants and their concentrations approximately reached to the concentrations of positive control (Fig.2).However, the combination of biofertilizer and ascorbic acid did not reach the concentrations of $\mathrm{Na}$ and $\mathrm{Cl}$ in okra plants to the concentrations of those elements in the control or salinity treated plants (Fig.2).

Figure (3) demonstrates the effects of different tested factors on some micro-nutrients in okra plants. For different salinity levels $\left(T_{3}\right.$ and $\left.T_{4}\right)$, it is recorded that $\mathrm{Fe}, \mathrm{Zn}, \mathrm{Mn}$, and $\mathrm{Cu}$ decreased with increasing salinity levels as compared with the control.
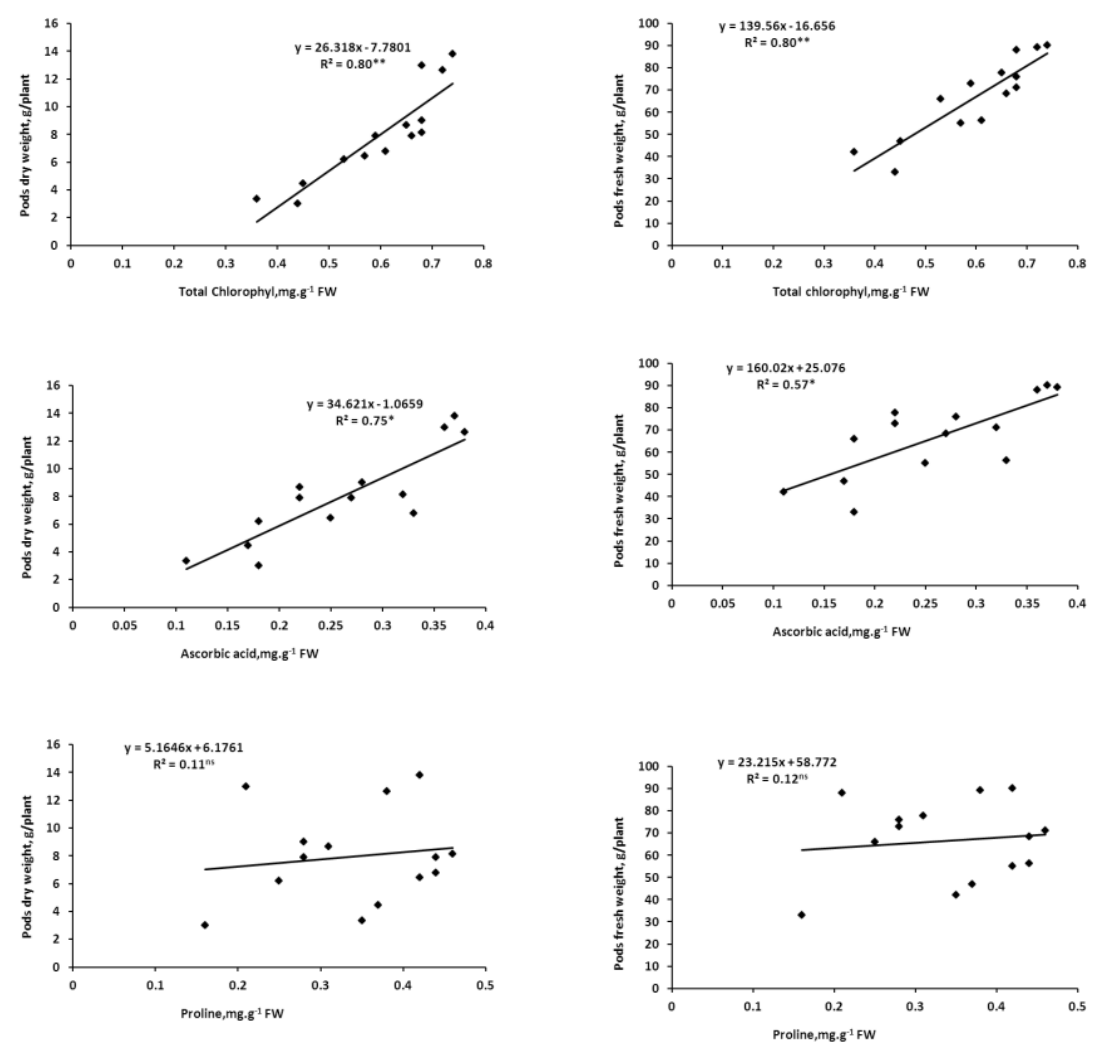

Fig.(3):Relationships between total chlorophyll, ascorbic acid, and proline concentrations in tissues and Pods dry and fresh weights of okra plants.

Figure (3) showed that salt stress caused significant reductions in micronutrients concentrations in okra plants in comparison of positive control $\left(T_{1}\right.$ and $\left.T_{2}\right)$. As for the effect of various tested treatments on micronutrients 
concentrations in okra plants, figure (3) indicated that addition of biofertilizer $\left(T_{5}\right.$ and $\left.T_{6}\right)$ significantly increased micro-nutrients concentrations in okra plants in comparison of salinity treated plants. Also, ascorbic acid foliar application $\left(T_{7}-T_{10}\right)$ significantly increased micro-nutrients concentrations in okra plants in comparison with salinity treated plants (fig.3). Moreover, the combined treatments of biofertilizer and ascorbic acid significantly ameliorate the negative effects of salinity levels on micro-nutrients concentrations in okra plants (fig.3). However, $\mathrm{T}_{11}\left(\right.$ Soil $+\mathrm{S}_{2}\left(2.00 \mathrm{dSm}^{-1}\right)+$ ascorbic acid $\left(100 \mathrm{mg}^{-\mathrm{I}^{-1}}\right)$ + biofertilizer) treatment was the best followed by $T_{12}>T_{13}>T_{14}$ treatments.

\section{DISCUSSION}

Plants grown under salt stress can use variety of strategies to counteract the adverse effects of salinity stress on their growth. Of these, ion homeostasis, enhanced antioxidant activity, and enhanced photosynthetic capacity are prominent. It is evident that salt tolerance in most crop plants is associated with a more efficient antioxidant system (Gossett et al., 1994, 1996; Noctor and Foyer, 1998; Mittova et al., 2002; Bor et al., 2003). An efficient antioxidant system includes enzymic (SOD, APX, and CAT), and non-enzymic antioxidants (ascorbate, tocopherols, salicylic acid, and carotenoids). Ascorbic acid (AsA) is one of the most important antioxidants protecting plants from oxidative stress (Smirnoff, 2005). Ascorbic acid is also involved in regulating photosynthetic capacity, flowering and senescence (Davey et al., 2000), and in counteracting adverse effects of salt stress in tomato (Shalata and Neumann, 2001) and in wheat (Al-Hakimi and Hamada, 2001).

In the present study, the high salinity of irrigation water supplied to soil may increase EC and soluble ions especially, $\mathrm{Na}$ and $\mathrm{Cl}$ concentrations. Salt stress caused a significant decrease in okra growth parameters, as salinity has both osmotic and specific ion effects on plant growth (Dionisio-Sese and Tobita 2000). The deleterious effect of salinity was attributed to salt induced stress, ion toxicity, ion imbalance or a combination of all these factors (Kurt et al., 1986). Salinity reduces height of plant and pods fresh and dry weights (Hamdy et al.1993; Essa 2002; Li et al.2006; Sharifi et al., 2007). Rengasamy (2002) interpreted that the growth reduction under saline condition may be due to low osmotic potentials resulting from salinity that can restrain water uptake by plants, which reduce their ability to survive and produce. Pods dry weight reduction due to salinity was explained by various works (Greenway and Munns 1980; Schwarz and Gale 1981; Walker et al., 1981) who stated that salinity causes physiological and biochemical disorder in plants.

Biofertilizer "Nitroben" is capable of affecting growth and yield of numerous plant species, as it is capable of producing various phytohormones that improve plant growth (Bashan et al., 2004).

Proline has a dual role in improving salt stress tolerance as it is able to act in a similar way to the peroxidase enzymes and scavenge reactive oxygen species (Zhu 2001). 
The results of the current research indicated that the added ascorbic acid improved the height and fresh and dry weights of okra plants. Consistent findings reported the beneficial effects exogenous

applications of ascorbic acid in mitigating partially the adverse effects of salt stress on growth (Mozafar and Dertli 1992).

The obtained results revealed significant interaction effects between $\mathrm{NaCl}$ stress and exogenous ascorbic acid on the contents of chlorophyll, since salt stress can lead to oxidative stress through the increase in reactive oxygen species (ROS) which are highly reactive and may cause cellular damage. One of the proposed biochemical modes of ascorbate is to act as an antioxidant by scavenging hydrogen peroxide (chloroplasts lack catalase) as it forms (Miyake and Asda 1992).

Some nutritional disturbances are expected under saline conditions, resulting in high ratios of $\mathrm{Na} / \mathrm{Ca}$ and $\mathrm{Na} / \mathrm{K}$. In the presence of excess $\mathrm{NaCl}$ in the growth medium, $\mathrm{Na}$ and $\mathrm{Cl}$ are accumulated in plant organs, and these ions can affect other mineral elements uptake through competition of membranes which causes nutrient deficiencies in plants (Bohra and Doffling 1993). It is clear, therefore, that salt stress had caused ion imbalance in okra plant.

\section{Conclusion}

This study showed the role of antioxidant to improve growth and nutrients contents of okra plants grown under moderate to high salinity. Inoculation with Nitrobacter sp. under salt stress is useful for improving nutrients status in tissues plants of okra grown under saline conditions. It can be concluded that the combination of biofertilizer with ascorbic acid is a new approach that appears to promote growth and yield and could be of interest for those seeking to improve salinity tolerance of crops.

\section{REFERENCES}

Al-Hakimi, A.M., and A.M. Hamada. 2001. Counteraction of salinity stress on wheat plants by grain soaking in ascorbic acid, thiamine or sodium salicylate.Biol. Plant. 44: 253-261.

Arnon,D.I.1949.Copper enzymes in isolated chloroplasts. Polyphenol-oxidase in Beta vulgaris.Plant Physiol.24:1-5.

AOAC (Association of Official Analytical Chemists).1995. Official Methods of Analysis, 15 th edn,AOAC, Washington.

Bashan,Y.,G.Holguin, and L.E.Bashan.2004.Azospirillum-plant relationships: physiological, molecular, agricultural and environmental advances.Can. J. Microbiol.50:521-577.

Bates,L.S.,P.R.Waldren, and I.D.Teare.1973. Rapid deterrmination of free proline for water stress studies.Plant Soil 39: 205-207.

Bohra,J.S., and K.Doffling.1993.Potassium nutrition of rice varities under $\mathrm{NaCl}$ salinity.Plant Soil 152:299-303. 
Bor, M., F.O" zdemir, and I.Tu"rkan .2003. The effect of salt stress on lipid peroxidation and antioxidants in leaves of sugar beet (Beta vulgaris L.) and wild beet (Beta maritime L.). Plant Sci. 164:77-84.

Bremner J.M. , and C.S.Mulvaney . 1982. Nitrogen-Total.In: Page A.L.,Miller R.H.,Keeney D.R. (eds): Methods of Soil Analysis, Am. Soc. of Agron., Madison, Wisconsin, USA.

Centritto, M., F.Loreto, and K. Chartzoulakis. 2003. The use of low [CO2] to estimate diffusional and non-diffusional limitations of photosynthetic capacity of saltstressed olive saplings. Plant Cell Environ. 26: 585-594.

Chen, Z., and D.R. Gallie. 2004. The ascorbic acid redox state controls guard cell signaling and stomatal movement. Plant Cell 16:1143-1162.

Davey, M., W.M.V.Montagu,D. Inze,M. Sanmartin, A. Kanellis, N Smirnoff,I.J.J. Benzie,J.J. Strain,D. Favell, and J.Fletcher. 2000. Plant I-ascorbic acid: chemistry, function, metabolism, bioavailability and effects of processing.J. Sci. Food Agric. 80: 825-860.

Day, P.R., 1965. Particle fraction and particle size analysis. In: Black A.C., Evans D.D., Ensminger L.E., White J.L., Clark F.E.(Eds): Methods of Soil Analysis, Part I. Am. Soc. of Agron., Madison, Wisconsin, USA.

Degl'Innocenti, E., C.Hafsi,L. Guidi, and F. Navari-Izzo.2009. The effect of salinity on photosynthetic activity in potassium-deficient barley species. J. Plant Physiol.166: 1968-1981.

Dionisio-Sese,M.L., and S.Tobita.2000.Effects of salinity on sodium content and photosynthetic responses of rice seedlings differing in salt tolerance.J. Plant Physiol 157:54-58.

Essa,T.A.2002. Effect of salinity stress on growth and nutrient composition of three soybean cultivars.J.Agron.Crop Sci.188:86-93.

FAO (Food and Agriculture Organization of the United Nations),.1976. Water quality for agriculture No.29 .FAO,Rome.

Foyer, C. H. 1993. Ascorbic acid. In R. G. Alscher \& J. L. Hess (Eds.), Antioxidants in higher plants (pp. 51-58). Boca Raton, FL:CRC Press.

Gossett, D.R., Banks, S.W., Millhollon, E.P., Lucas, M.C., 1996. Antioxidant response to $\mathrm{NaCl}$ stress in a control and a $\mathrm{NaCl}$-tolerant cotton line grown in the presence of paraquat, buthionine sulfoxime and exogenous glutathione.Plant Physiol. 112, 803-809.

Gossett, D.R., E.P.Millhollon, andM.C. Lucas.1994. Antioxidant response to $\mathrm{NaCl}$ stress salt-tolerant and salt-sensitive cultivars of cotton. Crop Sci. 34: 706-714.

Greenway, H., amd R. Munns.1980. Mechanism of salt tolerance in nonhalophytes.Annu. Rev. Plant Physiol. 31:149-159.

Hamdy,A., S. Abdul-Dayem, and M.Abu Zeid.1993. Saline water management for optimum crop production.Agric.Water Manag.24(3):189-203(Institute Agronomical Mediterranean Valenzany Bari, Italy)

Hegde, D.M., B.S. Dwived, and S.N. Sudhakara.1999. Biofertilizers for cereal production in India-a review. Indian J. Agric. Sci. 69:73-83. 
Hernández, J.A., A. Campillo,A. Jiménez, J.J. Alarcón, and F. Sevilla.1999. Response of antioxidant systems and leaf water relations to $\mathrm{NaCl}$ in pea plants. New Phytol.141: 241-151.

Jones J. B.,2001. Laboratory Guide of Conducting Soil Tests and Plant Analysis.CRC Press. New York, Washington D.C., USA.

Knudsen, D., G.A.Peterson, and P.F.Pratt.1982. Lithium,sodium and potassium. In :Page, A.L.,Miller R.H., Keeney, D.R.(eds): Methods of soil analysis, Am. Soc. Agron., Madison, Wisconsin, USA. p225--245

Kurt,E.,G.R.Cramer,A.Lauchi, and E.Epsetin.1986.Effect of $\mathrm{NaCl}$ and $\mathrm{CaCl}_{2}$ on cell enlargement and cell production in cotton roots. Plant Physiol 82:1102-1106.

Li,X.,P.An,S.Inanaga,A.G.Eneji, and K.Tanabe.2006. Salinity and defoliation effects on soybean growth.J.Plant Nutr.29:1499-1508.

Mittova, V., M.Guy, M.Tal, and M. Volokita. 2002. Response of the cultivated tomato and its wild salt-tolerant relative Lycopersicon pennellii to saltdependent oxidative stress: increased activities of antioxidant enzymes in root plastids. Free Radical Res. 36: 195-202.

Miyake,C., and K.Asda.1992. Thylakoid bound ascorbate peroxidase in spinach chloroplast and photoreduction of its primary oxidation product, monohydroascorbate radicals in the thylakoids.Plant Cell Physiol. 33:541-553.

Mozafar,A., and J.T.Dertli.1992.Uptake and transport of thianin (Vitamin B1) by barley and soybean.J.Plant Physiol.436:442

M"uller-Moul'e, P., T.Golan, and K.K. Niyogi. 2004. Ascorbate-deficient mutants of Arabidopsis grow in high light despite chronic photooxidative stress. Plant Physiol. 134: 1163-1172.

M"uller-Moul'e, P., M.Havaux, and K.K. Niyogi. 2003. Zeaxanthin deficiency enhances the high light sensitivity of an ascorbate-deficient mutant of Arabidopsis.Plant Physiol. 133: 748-760.

Nelson D.W, and L.E.Sommers .1982. Total Carbon, Organic Carbon and Organic Matter. In : Page A.L., Miller R.H. , Keeney D.R.(Eds.).Methods of Soil Analysis., Am. Soc. of Agron., Madison, Wisconsin, USA.

Nelson R.E.,1982. Carbonate and Gypsum. In : Page A.L., Miller R.H. , Keeney D.R.(Eds.).Methods of Soil Analysis., Am. Soc. of Agron., Madison, Wisconsin, USA, pp: 181-197.

Noctor, G., and C.H.Foyer. 1998. Ascorbate and glutathione: keeping active oxygen under control. Annu. Rev. Plant Physiol. Plant Mol. Biol. 49: 249-279.

Olsen, S.R., and L.E.Sommers.1982. Phosphorus., In: Page, A.L.,Miller, R.H., Keeney, D.R.(eds), Methods of soil analysis, Am. Soc. Agron., Madison, Wisconsin, USA. pp:403--427

Rhoades J.D.,.1982.Cation Exchange Capacity. In: Page AL, Miller R.H. , Keeney D.R.(Eds.).Methods of Soil Analysis., Am. Soc. of Agron., Madison, Wisconsin, USA. 
Richards L.A.,1954. Diagnosis and Improvement of Saline and Alkaline Soils. USDA Handbook 60.US Government Printing Office, Washington D. C.

Rengasamy,P.2002.Transient salinity and subsoil consttraints of dryland farming in Australian sodic soils.An overview.Aust.J. Exp.Agric.42:351361.

SAS Institute .1994. SAS/STAT User's Guide. Version 6.4th Ed. SAS Inst., Cary, N.C.

Schwarz,M., and J.Gale.1981. Maintenance respiration and carbon balance of plant at low levels of sodium chloride salinity.J.Exp.Bot.32:933-941.

Shalata, A., and P.M.Neumann. 2001. Exogenous ascorbic acid (Vitamin C) increases resistance to salt tolerance and reduced lipid peroxidation. J. Exp.Bot. 364: 2207-2211.

Sharifi,M.,M.Ghorbanli, and H.Ebrahimzadeh.2007. Improved growth of salinity-stressed soybean after inoculation with salt pre-treated mycorrhizal fungi.J.Plant Physiol. 164:1144-1151.

Smirnoff, N., 1995. Antioxidant systems and plant responses to the environment. In: Smirnoff, N. (Ed.) Environment and plant metabolism.Flexibility and acclimation.Bios.Scientific Publishers,Oxford,pp 217-243.

Smirnoff, N., 2000. Ascorbate biosynthesis and function in photo protection.Biol. Sci. 355: 1455-1465.

Smirnoff, N., 2005. Ascorbate, tocopherol and carotenoids: metabolism, pathway engineering and functions. In: Smirnoff, N. (Ed.), Antioxidants and Reactive Oxygen Species in Plants. Blackwell Publishing Ltd., Oxford, UK,pp. 53-86.

Suarez, D. 1992. Perspective on irrigation management and salinity. Outlook Agr. 21: 287-291.

Veljovic-Jovanovic, S.D., C.Pignocchi, G. Noctor, and C.H. Foyer. 2001. Low ascorbic acid in the vtc-1 mutant of Arabidopsis is associated with decreased growth and intracellular redistribution of the antioxidant system. Plant Physiol.127: 426-435.

Vessey, J.K.2003. Plant growth promoting rhizobacteria as biofertilizers. Plant Soil 255, 571-586.

Walker,P.R.,E.Torokfalvy,S.N.Stelle, and N.E.Kriedemann.1981. An analysis of photosynthetic response to salt treatment in Vitis vinifera.Aust.J.Plant Physiol.8:359-374.

Zhu,J.K.2001.Plant salt tolerance.Trends Plant Sci.6:66-71(http://cjm.nrc.ca) 
دراسة التأثير المتداخل للأسمدة الحيوية و مضادات الأكسدة على تقليل الأثر الضسار

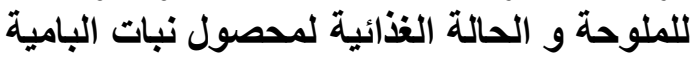

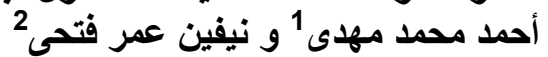

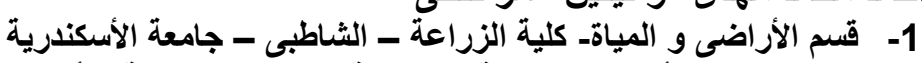

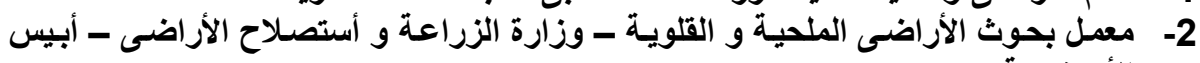

| - الأسكندرية

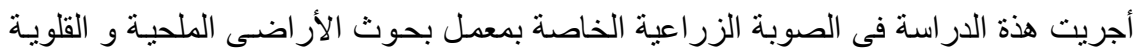

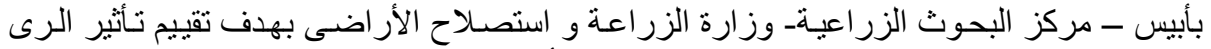

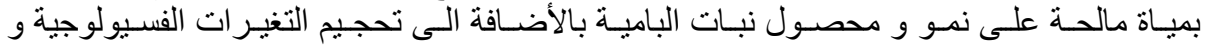

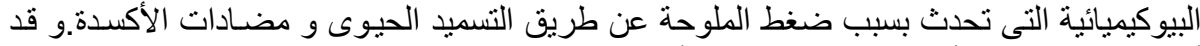

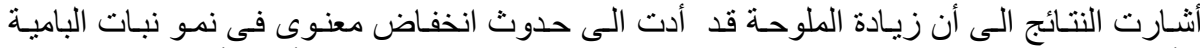

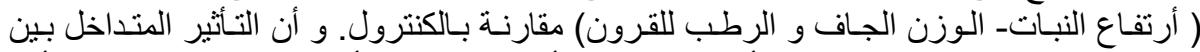

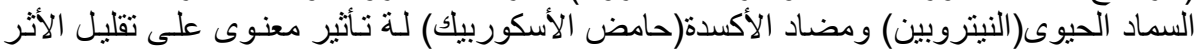

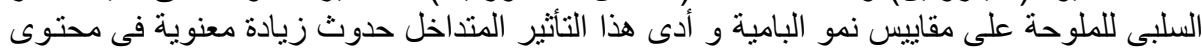

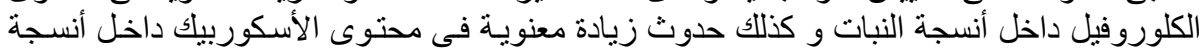

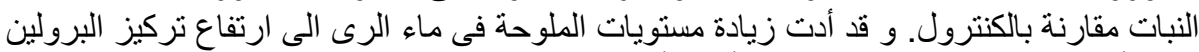

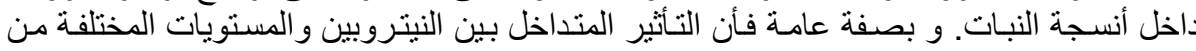

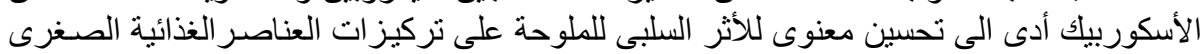

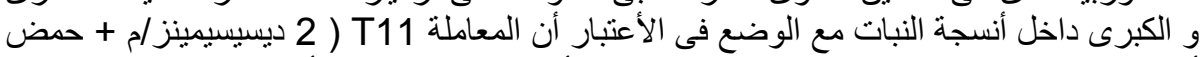

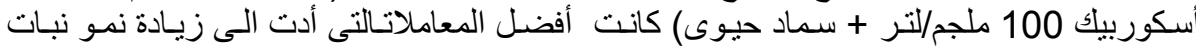

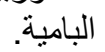

كلية الزراعة - جامعة المنصورة كلية الزراعة - جامعة الزعة جاسكندرية

\author{
قام بتحكيم البحث

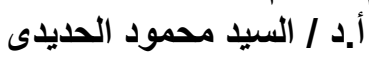

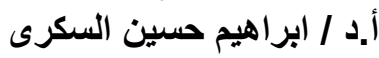

